\title{
Soil systemic insecticides to control the coffee leafminer, Leucoptera coffeella (Guérin-Méneville), in Puerto Rico'
}

\author{
Fernando Gallardo-Covas ${ }^{2}$
}

\begin{abstract}
Soil systemic insecticides were evaluated for the control of the coffee leafminer, Leucoptera coffeela, in 1982, 1983 and 1984 at the Adjuntas Agricultural Experiment Substation. Aldicarb $10 \mathrm{G}$ and carbofuran $10 \mathrm{G}$ were compared with a standard (disulfoton $15 \mathrm{G}$ ) and an untreated check. In 1982, disulfoton $15 \mathrm{G}$ af $12 \mathrm{~g} / \mathrm{m}$ height and aldicarb $10 \mathrm{G}$ at 20 and $30 \mathrm{~g}$ per tree $(93.3,75.3$ and $73.6 \%$ control, respectively) gave a highly significant leafminer control as compared with the check. Carbofuran 10 $G$ at $20 \mathrm{~g}$ per tree gave $68.6 \%$ control. For the second trial (1983) only aldicarb $10 \mathrm{G}$ at $20 \mathrm{~g}$ gave significantly higher pertentage control (20.9). In the third trial, disulfoton $15 \mathrm{G}$, aldicarb $10 \mathrm{G}$ at $20 \mathrm{~g}$ and $30 \mathrm{~g}$ per tree were highly significant with $92.6,87.8$ and $88.7 \%$ control, respectively. Also carbofuran $10 \mathrm{G}$ at $15 \mathrm{~g}$ per tree was significant. Yields in all treatments with aldicarb and carbofuran were superior to that with disulfoton $15 \mathrm{G}$ for the 3-year experiment.
\end{abstract}

\section{INTRODUCTION}

Coffee is one of the main agricultural crops of the island. It is grown in the west central area. Unshaded coffee is grown on approximately 81,715 acres. In 1983-84 coffee produced a cash value of $\$ 63.22$ million (4).

One of the limiting factors in coffee production is the coffee leafminer; the larvae of this small silvery moth bore into the mesophyll of the leaves and produce brown spots (fig. 1). This damage reduces $50 \%$ of the photosynthetic activity of the leaves, causes defoliation and reduces yields by up to $40 \%$ (3).

Leucoptera coffeella is the only species of the coffee leafminer complex (all belonging to the genus Leucoptera) found in the Neotropical region. It was discovered by Guérin-Méneville and Perrottet on coffee in Guadaloupe and Martinique (5). It was then placed in the genus Elachista and later referred to by Stainton (7) as Cemiostoma. Through a misidentification, the common Leucoptera found in Africa was referred to as coffeella in nearly all the literature up to 1958, when Bradley (2) eliminated the confusion by distinguishing it from $L$. meyricki.

The coffee leafminer (Leucoptera coffeella) occurs throughout the

'Manuscript submitted to Editorial Board May 29, 1986.

${ }^{2}$ Assistant entomologist, Crop Protection Department, Agricultural Experiment Station, University of Puerto Rico, Río Piedras, P. R. 


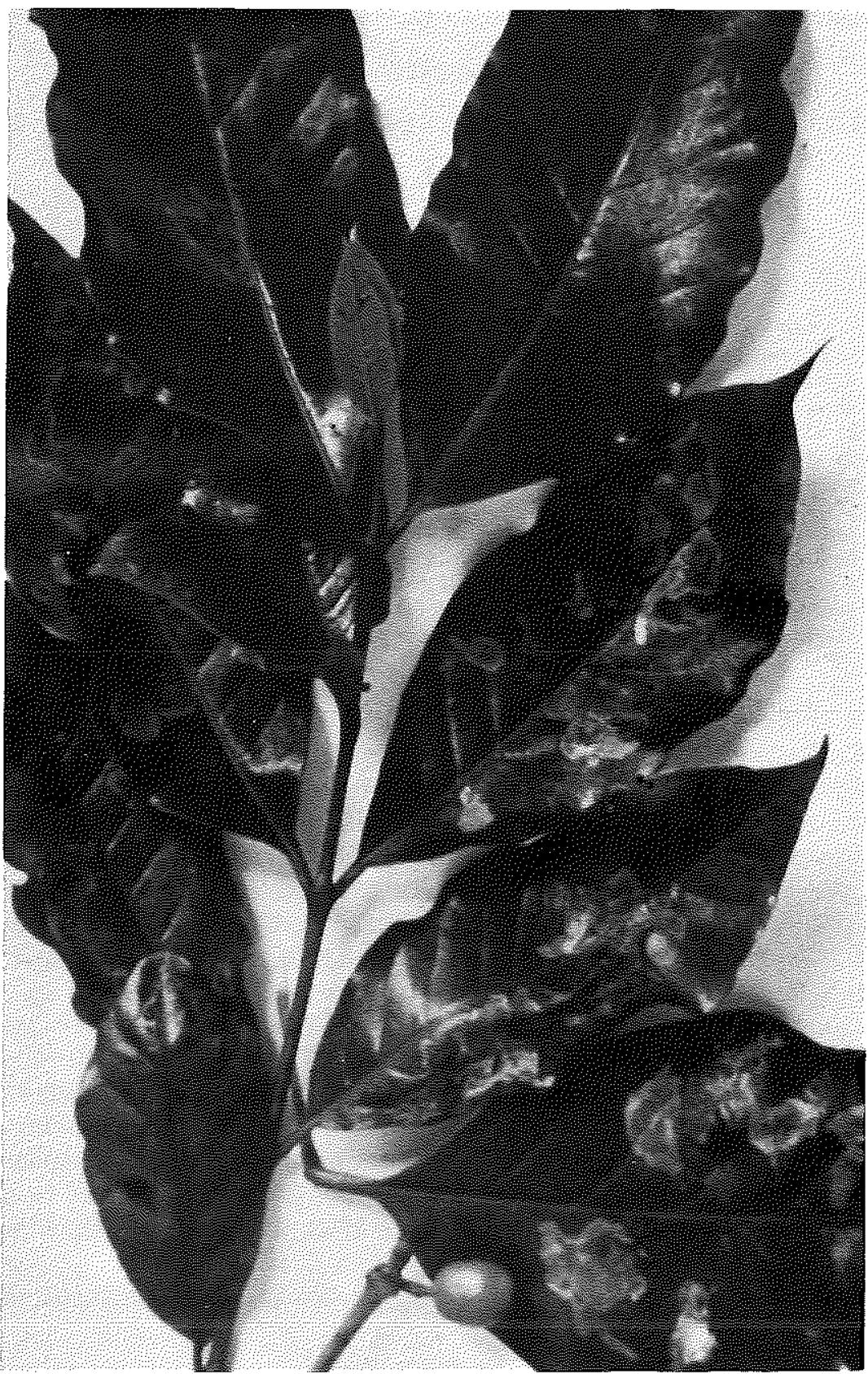

FIG. 1.-Damage caused to the coffee leaves by the coffee leafminer Leucoptera coffeella, Guérin-Méneville. 
Neotropical region in almost every country in which coffee is grown, and was probably introduced here with the first coffee plants brought to the island. The first record for Puerto Rico was reported by $O$. W. Barret in 1903 (1). Since then this insect has been studied, especially by Wolcott (9), Van Zwaluwenburg (8), Seín, and later by Pérez Escolar (6). Pérez Escolar conducted field trials and achieved the chemical control of the coffee leafminer with the systemic insecticide disulfoton $15 \mathrm{G}$. This insecticide has been the only effective pesticide registered in Puerto Rico for chemical control of the coffee leafminer during the last 20 years. Because of the possible development of resistance to this insecticide it has been necessary to evaluate other pesticides.

This paper summarizes the 1982-84 field experiments to evaluate different insecticides used against the coffee leafminer in coffee groves at the Adjuntas Agricultural Experiment Substations.

\section{MATERIALS AND METHODS}

A complete randomized design was established on unshaded coffee (cv. Bourbon) plots at the Adjuntas Agricultural Experiment Substation in January 1982 and was continued to 1984 . Soil systemic insecticide-nematicides previously selected from a preliminary screening were evaluated for the control of the leafminer. Carbofuran (Furadan) $10 \mathrm{G}$ and aldicarb (Temik) $10 \mathrm{G}$ were tested at three dosages (table 1). Disulfoton (Di-syston) $15 \mathrm{G}$ at one rate was included as standard, as well as an untreated check for comparison. Four replicates with eight trees each (10 years old, planted at $1.5 \times 3.3 \mathrm{~m}$ were used in an Alonso clay (Ultisols, $\mathrm{pH} 4.8$ and $3.15 \%$ organic matter).

Granules were spread and lightly worked around the root area or dripping line of the coffee shrub. All chemicals, except disulfoton $15 \mathrm{G}$, were applied twice during the year, the first application in February-

TABLE 1.-Percentage infestation, control and yield of coffee treated with different. pesticides against the coffee leafminer, Leucoptera coffeella, in Puerto Rico, 1982 trial

\begin{tabular}{lcccccr}
\hline \multirow{2}{*}{ Treatments } & \multirow{2}{*}{$\begin{array}{c}\text { Dosage } \\
\text { g/tree }\end{array}$} & & \multicolumn{2}{c}{ Percent } & & \multicolumn{2}{c}{ Yieid } \\
\cline { 6 - 7 } & & Infestation & Control & & kg/tree & $\begin{array}{r}\text { Percent } \\
\text { increase }\end{array}$ \\
\hline Carbofuran 10 G & 10 & 53.5 & 44.9 & 6.9 & 16.0 \\
Carbofuran 10G & 15 & 62.7 & 35.4 & & 6.1 & 5.2 \\
Carbofuran 10G & 20 & $30.5^{* 1}$ & 68.6 & & $7.9^{* * 2}$ & 26.1 \\
Aldicarb 10G & 10 & 64.5 & 33.6 & & $8.0^{* *}$ & 27.0 \\
Aldicarb 10G & 20 & $24.0^{* *}$ & 75.3 & & $7.6^{* *}$ & 23.2 \\
Aldicarb 10G & 30 & $25.7^{* *}$ & 73.6 & & $10.3^{* *}$ & 43.7 \\
Disulfoton 15G & $12 \mathrm{~g} / \mathrm{m}$ high & $6.5^{* *}$ & 93.3 & & 3.3 & - \\
Check & - & 97.2 & - & 5.8 & - \\
\hline
\end{tabular}

'Significantly different from the check at $\mathrm{P}=0.05$.

${ }^{2}$ Significantly different from the check at $\mathrm{P}=0.01$. 
April and the second in June-July in accordance with the seasonal activity of the coffee leafminer. Disulfoton $15 \mathrm{G}$ was applied once a year in February. All the agronomical practices common to the coffee region were followed in these experiments.

Counts to determine infestation percentage were done 2 months after each application. Four branches, randomly selected from each cardinal point of the tree, were observed and the number of mines recorded.

Observations were made between 1 and $2 \mathrm{~m}$ from the ground, where heavy populations of leafminer are frequently found.

Chemical effectiveness (percent control or P.C.) was estimated with a modification of the Abbott's formula as follows: $\frac{A-B}{A} \times 100$, where $A$ is infestation percentage in the check and $B$ the infestation percentage in the treated foliage. Percentage of insect control was statistically analyzed and differences between means evaluated for significance according to Student's " $t$ " or Duncan's new multiple range tests. Data on yield and phytotoxicity were also recorded.

\section{RESULTS AND DISCUSSION}

In the 1982 experiment (table 1) disulfoton $15 \mathrm{G}$ at the rate of $12 \mathrm{~g} / \mathrm{m}$ height gave the best percentage of leafminer control (93.31), which was highly significant $(\mathrm{P}<0.01)$ when compared with the check. It was followed by aldicarb $10 \mathrm{G}$ at the rate of 20 and $30 \mathrm{~g}$ per tree, with 75.3 and $73.6 \%$ control respectively $(\mathrm{P}=0.01)$ when compared with the check. Yield was higher with these treatments than with those of disulfoton 15 $\mathrm{G}$ and the check $(\mathrm{P}<0.01)$. The highest yield, $43.8 \%$, was obtained in plots treated with aldicarb $10 \mathrm{G}$ at the rate of 30 grams per tree when compared with the check. All treatments reduced a coffee leafminer populations. No phytotoxicity was observed in any of the treated plots.

For the second trial, 1983 (table 2), only aldicarb $10 \mathrm{G}$ at the rate of $20 \mathrm{~g} /$ tree gave significant control percentage (20.9) over other treatments $(\mathrm{P}<0.05)$. The remaining treated plots were not significantly different from the check. Low population of leafminer was observed during this trial in the field. No significant differences were observed in yield nor phytotoxicity on the treated plants. Nevertheless, some yield increase $(18.0 \%)$ was obtained in plots treated with aldicarb $10 \mathrm{G}$ at the rate of $10 \mathrm{~g} /$ tree.

A third experiment conducted in 1984 (table 3) showed that disulfoton $15 \mathrm{G}$ at the rate of $12 \mathrm{~g}$ per $1 \mathrm{~m}$-high tree gave the best leafminer control (92.6\%), significant $(\mathrm{P}=0.01)$ when compared with the check. It was followed by aldicarb $10 \mathrm{G}$ at 30 and $20 \mathrm{~g} /$ tree with 88.7 and $80.8 \%$ control, respectively. Also carbofuran $10 \mathrm{G}$ at $20 \mathrm{~g} /$ tree with $73.8 \%$ control was significantly different from the check $(\mathrm{P}=0.01)$. Carbofuran $10 \mathrm{G}$ at the rate of $15 \mathrm{~g} /$ tree with $65.8 \%$ control was significant $(\mathrm{P}=0.05)$ when 
TABLE 2.-Percentage infestation, control and yield of coffee treated with different pesticides against the coffee leafminer, Leucoptera coffeella, in Puerto Rico, 1983 trial

\begin{tabular}{lcccccc}
\hline \multirow{2}{*}{ Treatments } & \multirow{2}{*}{$\begin{array}{c}\text { Dosage } \\
\text { g/tree }\end{array}$} & \multicolumn{2}{c}{ Percent } & & \multicolumn{2}{c}{ Yield } \\
\cline { 3 - 4 } \cline { 5 - 7 } & & Infestation & Control & & kg/tree & $\begin{array}{c}\text { Percent } \\
\text { increase }\end{array}$ \\
\hline Carbofuran 10G & 10 & 47.7 & - & 9.0 & 9.3 \\
Carbofuran 10G & 15 & 42.2 & 7.9 & 7.9 & - \\
Carbofuran 10G & 20 & 42.3 & 7.7 & & 8.7 & 6.6 \\
Aldicarb 10G & 10 & 47.5 & - & 9.9 & 18.0 \\
Aldicarb 10G & 20 & $36.3^{*}$ & 20.9 & & 8.6 & 5.0 \\
Aldicarb 10G & 30 & 39.6 & 13.8 & & 8.9 & 9.0 \\
Disulfoton 15G & $12 \mathrm{~g} / \mathrm{m}$ high & 46.8 & - & & 9.1 & 11.0 \\
Check & - & 45.9 & - & 8.1 & - \\
\hline
\end{tabular}

${ }^{1}$ Significantly different from the check at $\mathrm{P}=0.05$.

TABLE 3.-Percentage infestation, control and yield of coffee treated with different pesticides against the coffee leafminer, Leucoptera coffeella, in Puerto Rico, 1984 trial

\begin{tabular}{lcccccc}
\hline \multirow{2}{*}{ Treatments } & \multirow{2}{*}{$\begin{array}{c}\text { Dosage } \\
\text { g/tree }\end{array}$} & \multicolumn{2}{c}{ Percent } & & \multicolumn{2}{c}{ Yield } \\
\cline { 3 - 4 } \cline { 5 - 6 } & & Infestation & Control & & kg/tree & $\begin{array}{c}\text { Percent } \\
\text { increase }\end{array}$ \\
\hline Carbofuran 10G & 10 & 9.7 & 48.7 & 9.4 & - \\
Carbofuran 10G & 15 & $6.5^{* 1}$ & 65.8 & & 12.0 & 15.8 \\
Carbofuran 10G & 20 & $4.9^{* * 2}$ & 74.0 & & 10.9 & 7.9 \\
Aldicarb 10G & 10 & 8.7 & 54.0 & & 10.9 & 8.0 \\
Aldicarb 10G & 20 & $3.6^{* *}$ & 80.8 & & 10.8 & 6.8 \\
Aldicarb 10G & 30 & $2.1^{* *}$ & 88.7 & & 10.2 & 0.9 \\
Disulfoton 15G & $12 \mathrm{~g} / \mathrm{m}$ high & $1.4^{* *}$ & 92.6 & & 10.2 & 1.4 \\
Check & - & 19.0 & - & & 10.1 & - \\
\hline
\end{tabular}

${ }^{1}$ Significantly different from the check at $\mathrm{P}=0.05$.

"Significantly different from the check at $\mathrm{P}=0.01$.

compard with the check. No significant differences were established between yields of treated plots and the check. However, plots treated with carbofuran $10 \mathrm{G}$ at $15 \mathrm{~g} /$ tree showed an increase of $15.8 \%$ when compared with the check. No phytotoxicity was observed in treated plots.

The total accumulated control percentage of the coffee leafminer for the 3 years (table 4 ) showed that disulfoton $15 \mathrm{G}$ and aldicarb $10 \mathrm{G}$ at 20 and 30 grams per tree gave the highest value, followed by carbofuran 10 $\mathrm{G}$ at the rate of $20 \mathrm{~g} /$ tree. The lowest control percentage (29.1) was obtained with aldicarb $10 \mathrm{G}$ at $10 \mathrm{~g} /$ tree. All the treatments were effective in controlling the coffee leafminer.

The total yield for the 3 years (table 4 ) showed that aldicarb $10 \mathrm{G}$ at $30 \mathrm{~g} /$ tree gave the highest yield $(9.8 \mathrm{~kg} /$ tree) followed by aldicarb $10 \mathrm{G}$ at $10 \mathrm{~g}$ and carbofuran $10 \mathrm{G}$ at $20 \mathrm{~g} /$ tree. All the treated plots were higher 
TABI.E 4.-Average percentage control of the coffee leafminer, Leucoptera coffeella, and average yield per tree on coffee plot treated with different soil systemic insecticide-nematicides, 1982-84 trial, Adjuntas, $P$. R.

\begin{tabular}{lcccc}
\hline \multirow{2}{*}{ 'Theatments } & $\begin{array}{c}\text { Dosage } \\
\text { g/tree }\end{array}$ & $\begin{array}{c}c \\
\text { Percent } \\
\text { control }\end{array}$ & $\begin{array}{c}\text { Yield } \\
\text { kg/tree }\end{array}$ & \% Yield increase \\
\hline Carbofuran 10G & 10 & 31.2 & 8.4 & 11.7 \\
Carbofuran 10G & 15 & 36.3 & 8.7 & 12.0 \\
Carbofuran 10G & 20 & 50.1 & 9.2 & 12.7 \\
Aldicarb 10G & 10 & 29.2 & 9.6 & 24.0 \\
Aldicarb 10G & 20 & 59.0 & 9.0 & 12.5 \\
Aldicarb 10G & 30 & 58.7 & 9.8 & 24.5 \\
Disulfoton 15G & 12 g/m height & 62.0 & 7.6 & - \\
Check & - & - & 8.0 & - \\
\hline
\end{tabular}

in yield than those treated with disulfoton $15 \mathrm{G}$, probably because of the nematicidal action of aldicarb and carbofuran. In conclusion, these experiments showed that aldicarb $10 \mathrm{G}$ and carbofuran $10 \mathrm{G}$ have the potential to control the coffee leafminer.

\section{RESUMEN}

Insecticidas sistémicos para reprimir del minador de la hoja del cafeto, Leucoptera coffeella (Guérin-Méneville), en Puerto Rico

Se evaluaron varios insecticidas-nematicidas para controlar el minador del cafeto, Leucoptera coffeella, en la Estación Experimental Agrícola, Subestación de Adjuntas, Puerto Rico, de el 1982 a 1984 . Aldicarb $10 \mathrm{G}$ y carbofuran $10 \mathrm{G}$, ambos en 3 dosis, se aplicaron en un ensayo en 1981. Se incluyó, además, el insecticida disulfoton $15 \mathrm{G}$ como testigo para compararlos. En el primer ensayo (1982) disulfoton $15 \mathrm{G}$ fue altamente significativo en el control del minador (93.3\%) al compararlo con el del testigo. Con aldicarb $10 \mathrm{G}$ en dosis de 20 y $\mathbf{3 0}$ gramos por árbol se obtuvo 75.3 y $73.6 \%$ de control, respectivamente. El control de carbofuran $10 \mathrm{G}$ en dosis de 20 gramos por árbol fue singificativo al $5 \%$ al compararlo con el del testigo. En el segundo año solamente aldicarb $10 \mathrm{G}$ en dosis de 20 gramos controló el minador significativamente al $5 \%$ al compararlo con el del testigo. No fue posible determinar si hubo diferencias significativas entre los demás tratamientos. En el tercer año, los resultados demostraron que disulfoton $15 \mathrm{~g}$ con $92.6 \%$ de control, aldicarb $10 \mathrm{G}$ en 30 y 20 gramos con 88.7 y $80.8 \%$ de control, respectivamente, fueron altamente significativos. Con carbofuran $10 \mathrm{G}$ a 15 gramos por árbol se obtuvo un control significativo al $5 \%$. Con todos los tratamientos de aldicarb $10 \mathrm{G}$ y carbofuran $10 \mathrm{G}, 10$ cual podría atribuirse a la acción nematicida de dichos productos. En conclusión, ambos productos, aldicarb y carbofuran, demostraron ser eficaces en el control del minador del cafeto en Puerto Rico.

\section{LITERATURE CITED}

1. Barret, O. W., 1904. Ann. Rep. P. R. Agrie. Exp. Stn., 1908, pp. 429-50, Washington, D.C. 
2. Bradley, J. D., 1958. 'Taxonomic notes on Leucoptera meyricki Chesquiere and Leucoptera coffeella (Guérin-Méneville). Bull. Entomol. Res., 48, 417-19.

3. Cibes, H. R. and Pérez, M., 1958. Minador de la hoja disminuye en grado considerable el vigor de los cafetos. El café de El Salvador, 28: 325-26.

4. Deynes-Soto, R., 1985. Informe económico de la empresa de café, Reunión de la empresa del café, marzo 18, 1985. Univ. P. R. Recinto de Mayagüez, S.E.A., Mayagüez P. R.

5. Guérin-Méneville and Perrottet, 1842. "Mémoir sur un insecte et un champignon que ravagent les caférs aux Antilles", Min, Marine, 1-32, 2 pl, París.

6. Pérez-Escolar, M. E., 1962. Recomendaciones para controlar el minador del café con el insecticida sistémico Di-syston. Esta. Exp. Agric., Univ. P. R. Río Piedras, P. R. Publ. Misc. 42.

7. Stainton, H. T., 1961. Entomology Weekly Intellig., X, pp. 110-11.

8. Van Zwaluwenberg, R. H., 1917. Insects affecting coffee in Puerto Rico. J. Econ. Entomol; $10(6): 513-17$.

9. Wolcott, G. N., 1947. A quintessence of sensitivity: The coffee leafminer. J. Agric. Univ. P. R., 31 (3): 215-19. 